CORRIGENDA

\title{
The mir-34 microRNA is required for the DNA damage response in vivo in C. elegans and in vitro in human breast cancer cells
}

M Kato, T Paranjape, RU Müller, S Nallur, E Gillespie, K Keane, A Esquela-Kerscher, JB Weidhaas and FJ Slack

Oncogene (2009) 28, 3008; doi:10.1038/onc.2009.218

Correction to: Oncogene (2009) 28, 2419-2424; doi:10.1038/onc.2009.106; published online 4 May 2009 of the third author was incorrectly presented. The corrected author list is given above.

Since the publication of the above paper, the authors have identified an error in the author list; the name

\section{Tumor necrosis factor receptor-associated factor-1 enhances proinflammatory TNF receptor-2 signaling and modifies TNFR1-TNFR2 cooperation}

\author{
A Wicovsky, F Henkler, S Salzmann, P Scheurich, C Kneitz and H Wajant
}

Oncogene (2009) 28, 3008; doi:10.1038/onc.2009.219

Correction to: Oncogene (2009) 28, 1769-1781; doi:10.1038/onc.2009.29; published online 16 March 2009

The authors found that the Colo205 cells used were derived from incorrectly labelled HeLa-TNFR2 stocks.
The incorrect identification of the cells does not affect the validity of our data and does not limit the conclusions drawn in our paper. The authors apologize for this mistake in cell identity and for any inconvenience caused thereby. 